\title{
5. Nuclear Secrets and Interpretations of the Diefenbaker Government's Demise, 1962-63
}

\author{
Michael Stevenson
}

Michael D. Stevenson is Associate Professor of History at Lakehead University specializing in military and diplomatic history. He is the author of Canada's Greatest Wartime Muddle: National Selective Service and the Mobilization of Human Resources during World War II (MQUP, 2001), and he has edited three volumes of the Documents on Canadian External Relations series focusing on the John Diefenbaker government. He is currently writing a book on Canadian-American relations during the Eisenhower administration, and a biography (with Eric Bergbusch) of Howard Charles Green, Canada's foreign minister from 1959 to 1963.

mstevens@lakeheadu.ca

The collapse of John Diefenbaker's Progressive Conservative government in February 1963 capped three months of turbulent negotiations with the United States over the acquisition of nuclear weapons for Canadian forces. Despite the importance of this event in post-1945 Canadian political history, the closure of government files in Canada and the United States relating to nuclear weapons for nearly fifty years prevented a thorough and complete analysis of the circumstances relating to the near breach in Canadian-American relations in 1963 and the resulting fall of the Diefenbaker government. Historians instead relied heavily on memoirs and recollections of key Cabinet ministers involved in the situation to attempt to explain Diefenbaker's demise. The recent opening, however, of these formerly classified government files and the use of previously ignored private papers has allowed a full picture of the 1962 to 1963 nuclear weapons negotiations to be determined and demonstrates the critical utility of open archives in understanding Canada's nuclear history. 
The broad outlines of the closing months of the Diefenbaker government and the bilateral dispute concerning nuclear weapons can be quickly provided. The Canadian Cabinet had split over the question of nuclear arms, with a pro-acquisition faction led by Defence Minister Douglas Harkness and an anti-acquisition faction led by Secretary of State for External Affairs Howard Green failing to convince prime minister Diefenbaker to make a final determination. But the debacle of the Cuban Missile Crisis finally convinced Diefenbaker to launch serious and sustained negotiations with the Kennedy administration. In November and December 1962, Canadian and American representatives met in Ottawa to hammer out an agreement that eventually centred on a "missing part" formula. This would see US nuclear warheads stationed on Canadian soil for use in CF-101 interceptors and Bomarc missile squadrons minus one critical component that would be flown from the United States to Canadian bases once a specified NORAD alert level had been reached. These negotiations did not result in a breakthrough, however, and the Kennedy administration determined to avoid resuming them in the hope that a possible election would remove Diefenbaker from the political scene.

Early in 1963, retiring NATO commander Lauris Norstad's public declaration that Canada was shirking its NATO obligations by not accepting nuclear missile tips, Lester Pearson's decision to commit the Liberal Party to nuclear weapons acquisition, and the arrival in Ottawa of a tough-minded diplomatic brawler, Walton Butterworth, as the new US ambassador, pushed Diefenbaker to strike a four-member Cabinet committee to arrive at an official policy on nuclear weapons, a policy document Diefenbaker immediately rejected. The prime minister 
then made the mistake of revealing the existence of the top-secret nuclear negotiations with the United States in a speech to the House of Commons on January 25, 1963, causing an unprecedented rebuke from Washington in the form of a State Department press release on January 30. Unable to remain in Cabinet without a firm commitment from Diefenbaker, Defence Minister Harkness resigned, and the Diefenbaker government fell over a nonconfidence motion on February 5, 1963.

The broad, non-specific outlines of this chronology have been well known to historians. For decades, scholars relied primarily on the personal recollections and published memoirs of the Canadian Cabinet ministers involved in the nuclear weapons debate of 1962 and 1963, most notably those of Donald Fleming and Douglas Harkness. Harkness's interpretation has served as the major primary source in the traditional approach explaining the final months of the Diefenbaker government. Traveling across the Atlantic by boat in August 1963, Harkness composed a seventy-four page memorandum titled "The Nuclear Arms Question and the Political Crisis Which Arose from It in January and February 1963" that provided his viewpoint of the nuclear weapons crisis. ${ }^{1}$ It cannot be contested that this document is a valuable source, but it is obviously presenting Harkness' side of the debate alone, and the memorandum also avoids many of the technical details of the bilateral negotiations between Ottawa and Washington that took place in November and December 1962. Nonetheless, many biographical and policy accounts of the period use Harkness as an unimpeachable and unbiased source. In his excellent biography of Diefenbaker, for example, Denis Smith relies on Harkness' 1963 memorandum more heavily than any other single source. Most of these personal accounts tend 
to endorse the pro-nuclear weapons acquisition faction within the Progressive Conservative government and present a somewhat unbalanced account of the remarkably complex array of factors at play in the final months of the Diefenbaker regime.

Three critical archival sources relating to the 1962 to 1963 nuclear crisis, however, have been opened or utilized recently, providing a much more nuanced picture that undermines the existing negative interpretation of Diefenbaker's management of the nuclear weapons file.

First, Department of External Affairs records related to the crisis have been recently published in Volume 29 of the Documents on Canadian External Relations series that provide the intricacies of the nuclear negotiations between Canadian and American officials. ${ }^{2}$ Second, the comprehensive documentation housed in the John F Kennedy Presidential Library dealing with Kennedy's relationship with Diefenbaker has been declassified, and it focuses on the decisions taken in January 1963 leading up to the release of the State Department press release on January 30. Finally, the detailed private correspondence of Howard Green has become known after being largely ignored by a generation of Canadian historians. Using these sources, a case study examining nuclear diplomacy in 1962 and 1963 that at least partially rehabilitates Diefenbaker's political reputation demonstrates the importance of open archives and shines new light on the history of Canada's nuclear weapons experience.

The Documents on Canadian External Relations volumes published by the Department of Foreign Affairs and International Trade over a period of many decades have proved invaluable in documenting Canada's nuclear history. Successive editors of DCER volumes select critical documents relating to nuclear arms and subject them to the declassification process, 
resulting in their publication and availability to scholars for the first time. Volume 29 in the DCER series was published in 2013 and allowed the full details of the negotiations to arm Canadian forces with nuclear weapons to be ascertained for the first time. The initial round of negotiations occurred in Ottawa on November 21 and 23, 1962. For interceptors and Bomarc missiles in Canada, a variety of options were discussed, including the storage of the warheads on transport aircraft at US bases on permanent standby to be flown to Canada when a specific alert status was reached or the tactical ferrying of CF-101 interceptor aircraft to US bases during an emergency to allow the MB-1 air-to-air rocket to be installed. Both options were not realistic in terms of the cost and time involved, and the missing part idea was initially discussed. A second round of negotiations took place on December 4 and 5, and it was determined that for Bomarc missiles, an arming plug for the warhead could be flown in to have Bomarc batteries operational in less than three hours. For the MB-1 rocket for CF-101 interceptors, two potential missing parts in the form of an umbilical power cable and an ejector rack were identified, with arming times ranging from one to four hours. Although Canadian negotiators believed that a workable agreement could be reached, senior officials in Washington determined these plans were not workable and too "contrived" to be considered realistic from a defence perspective. The two documents published in the DCER for the first time provide this rich detail. The first document has not been previously available at all to historians, while the second document was present in the LAC personal collections of Howard Green and AE Ritchie but not widely referenced. 
Recently declassified sources from the United States, particularly those housed in the Kennedy Library, further illuminate the contentious issue of arming Canadian forces with nuclear weapons. Some of these previously restricted documents concern the Ottawa negotiations over the arming of Canadian Bomarcs and CF-101 aircraft and confirm the details provided in the DCER collection, with an obvious slant regarding the artificiality of the proposals concerning the missing part instead of Canada simply accepting the complete warheads and housing them on Canadian soil. The most detailed and informative documents from the Kennedy Library concern the development, forcefully advocated by Walton Butterworth, of a well-defined plan to destabilize the Diefenbaker government as the Canadian prime minister's difficulties mounted in January 1963. These plans were undertaken with the knowledge of the White House, as evidenced by a declassified document from Lawrence Legere to President Kennedy on January 21, 1963 recommending that no concessions be granted to Diefenbaker. "On balance," Legere noted, "it seems best to stand fast. This course is easy to justify militarily... and it could materially enhance Diefenbaker's difficulties as the election approaches." ${ }^{3}$ This policy was clearly made more punitive after Diefenbaker's gaffe in Parliament revealing the existence of the bilateral nuclear negotiations that led to the State Department press release.

Finally, the necessity of open archives in the accurate analysis of Canada's nuclear history is evident in the remarkable personal papers of Howard Green contained in the City of Vancouver Archives. This collection has been accessible for decades, but nuclear policy historians have largely ignored it. The most valuable historical material in the Green papers 
comes from his personal correspondence. Over the course of his political career, he penned thousands of letters to his family providing a detailed analysis of events in Ottawa. His observations are not more or less valuable than widely cited memoirs or accounts written by people such as Douglas Harkness, but it is important to include Green's previously ignored letters because they add balance to the debate about the downfall of the Diefenbaker government.

Green has frequently been portrayed as a naïve, inexperienced practitioner of foreign policy, but he genuinely believed that his campaign for international disarmament and the acceptance of nuclear weapons on Canadian soil were incompatible policy goals. His correspondence adds colour to the events of 1962 and 1963 in many areas. He offered a strong commentary, for example, on Lester Pearson's decision to commit the Liberal Party to accepting nuclear warheads: "I think it takes us off several hooks and I can't understand why he didn't sit tight and let us stew! Strange fellow - intrinsically a weak sister, I think. He should have stayed with diplomacy!"4 Similarly, Green recalled January 30 as "the day the State Department did us dirt... I saw the US press release first when handed it by a Canadian reporter! How on earth the US government expects to hold friends is beyond me - but they may not care. I think this is the time that Canada must stand up to them if she is not to become a satellite."5

In conclusion, therefore, this micro-study of the 1962 to 1963 nuclear weapons crisis demonstrates the vital importance of open archives to provide a more thorough understanding of the nature of Canadian-American relations during the Cold War. Scholars examining the 
bilateral association are divided into two general factions. One group led by John Herd Thompson and Stephen J. Randall contends that a general ambivalence marked dealings between Ottawa and Washington after 1945, particularly from the American side. ${ }^{6}$ The opposing group led by Robert Bothwell argues that the bilateral connection reflected a special bond or unique partnership between the two countries. ${ }^{7}$ The tumultuous events in the closing months of the Diefenbaker government conclusively demonstrate that Canada was anything but "invisible and inaudible" in Washington. ${ }^{8}$ Diefenbaker's attempt to adopt autonomous policies threatening to unravel increasingly integrated bilateral defense connections clearly alarmed the Kennedy Administration. In response, Washington launched an unprecedented diplomatic campaign to destabilize the Conservative government and either force Ottawa to accede to American demands or, preferably, to topple Diefenbaker and allow a Liberal government to re-establish the special relationship between the two countries that had prevailed since the Second World War. ${ }^{9}$ 


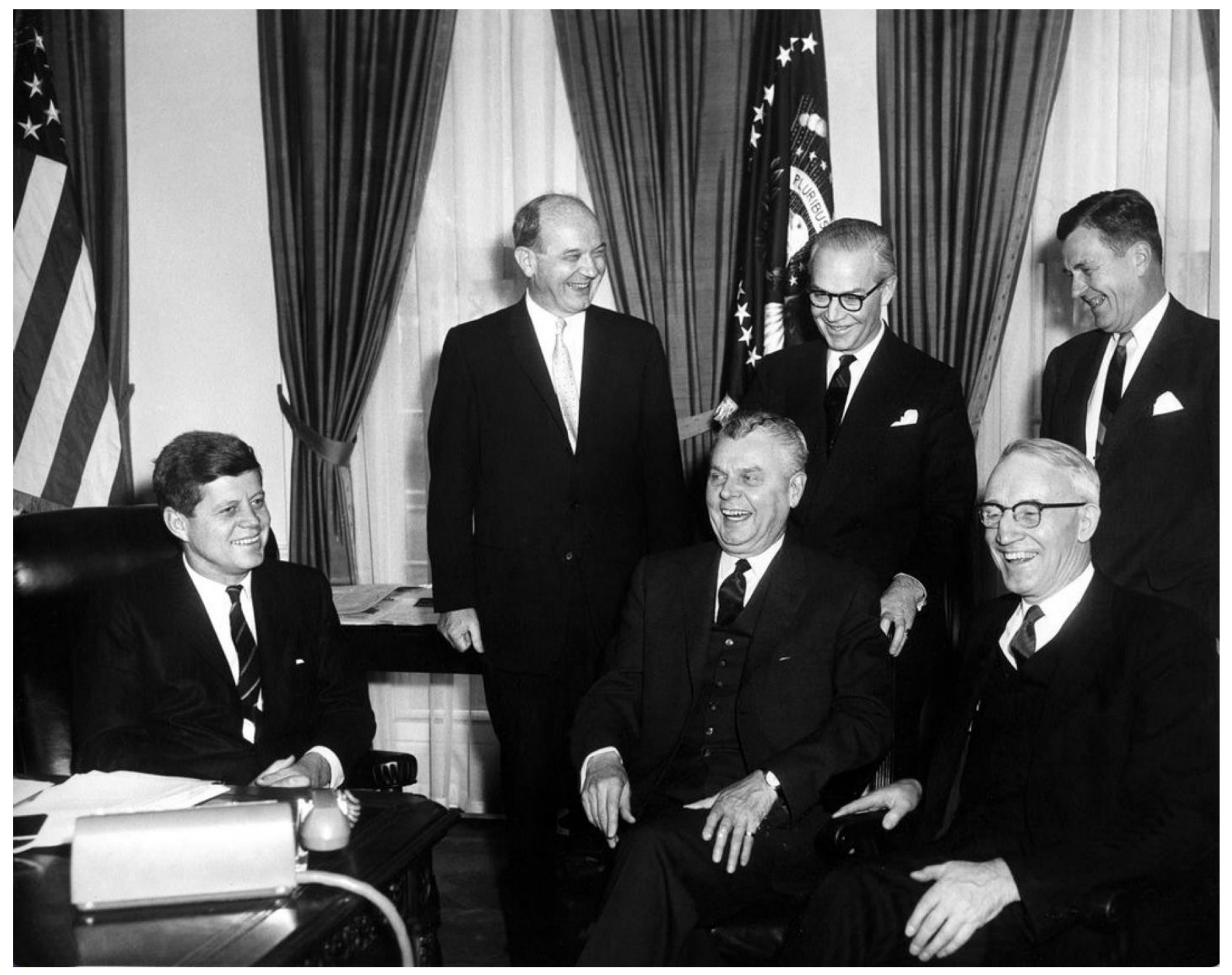

Figure 2. President John F. Kennedy Meets with Prime Minister John G. Diefenbaker of Canada and Others. White House Photographs. Canadian Prime Minister John Diefenbaker and Secretary of State for External Affairs Howard Green visited Washington to meet with United States President John F. Kennedy on February 20, 1961. In office only a month at this point, Kennedy pressed his counterpart on Canada's willingness to acquire American nuclear warheads for weapon systems Canada had acquired to fulfil its NORAD and NATO obligations. Diefenbaker, conscious of strong opposition within segments of the Canadian electorate to nuclear weapons, and Green, a strident champion of international disarmament, played key roles in the Progressive Conservative government's ultimate refusal to station nuclear weapons in Canada, and the Diefenbaker government collapsed over the issue in February 1963. In the photograph, seated (left to right) are Kennedy, Diefenbaker, and Green. Standing behind them (left to right) are US Secretary of State Dean Rusk, Canadian Ambassador to the United States Arnold Heeney, and American Ambassador to Canada Livingston Merchant. (Photograph by Abbie Rowe. AR6363-A, John F. Kennedy Presidential Library and Museum, Boston. https://www.jfklibrary.org/assetviewer/archives/JFKWHP/1961/Month\%2002/Day\%2020/JFKWHP-1961-02-20C?image identifier=JFKWHP-AR6363-A. Photograph is in the Public Domain.) 
1 "The Nuclear Arms Question and the Political Crisis Which Arose from It in January and February 1963," Douglas Harkness Papers, MG 32 B19, Volume 57, Library and Archives Canada.

2 Janice Cavell, ed., Documents on Canadian External Relations, 1962-1963, Volume 29 (Department of Foreign Affairs, Trade and Development Canada, 2013).

${ }^{3}$ Legere to Kennedy, January 21, 1963, National Security Files, Box 225, File NATO, Weapons, Cables, Canada, 12/61-11/63, part 1, John F. Kennedy Presidential Library.

${ }^{4}$ Green to F. Green, January 13, 1963, Howard C. Green Papers, Series 593-E-6, File 6, City of Vancouver Archives.

${ }^{5}$ Green to F. Green, February 3, 1963, Howard C. Green Papers, Series 593-E-6, File 7, City of Vancouver Archives.

${ }^{6}$ John Herd Thompson and Stephen J. Randall, Canada and the United States: Ambivalent Allies, 4th ed. (University of Georgia Press, 2008). 1992).

${ }^{7}$ Robert Bothwell, Canada and the United States: The Politics of Partnership (Twayne,

${ }^{8}$ Edelgard Mahant and Graeme S. Mount, Invisible and Inaudible in Washington: American Policies towards Canada during the Cold War (UBC Press, 1999).

9 "'Tossing a Match into Dry Hay': Nuclear Weapons and the 1962-63 Crisis in CanadianAmerican Relations," Journal of Cold War Studies 16 (4) (2014): 5-34. 